\title{
Understanding of Mathematical Concepts in the Linear Equation with Two Variables: Impact of E-Learning and Blended Learning Using Google Classroom
}

\author{
Syamsul Huda ${ }^{1}$, Mu'min Firmansyah $^{2}$, Achi Rinaldi ${ }^{3}$, Suherman $^{4}$, Iip Sugiharta ${ }^{5}$, Dian \\ Widi Astuti $^{6}$, Okis Fatimah ${ }^{7}$, Andika Eko Prasetyo \\ ${ }^{1,2}$ IAIN Kediri, Indonesia \\ 3,4,5,6,7 Universitas Islam Negeri Raden Intan, Indonesia \\ ${ }^{8}$ University of Melbourne \\ ${ }^{1}$ Correspondence Adress; Syamsul_Huda63@yahoo.co.id
}

\begin{abstract}
Students need an understanding of mathematical concepts provided by educators who have good skills. Educators must also maximize their teaching time so that it requires learning models such as e-learning and blended learning to meet the loss of teaching time due to other activities that must be done by the teacher besides teaching. This study aims to see the impact of blended learning and e-learning on the ability to understand mathematical concepts of students in the material of two-variable linear equations. The method used in this study is the quasi-experiment with the posttest only control design research. Technical analysis uses one way ANOVA. Based on the results of the study, Blended Learning and E-Learning influence understanding mathematical concepts in the two-variable linear equation material, so that it can be used as a knowledge given to students in understanding mathematical concepts.
\end{abstract}

Keywords: Blended Learning; E-learning; Google Classroom; Understanding of mathematical concepts

\section{INTRODUCTION}

Education built on 21st-century competencies focuses on learning that requires students to have skills, knowledge, understanding of concepts, and abilities in the fields of technology, media, and information. One of the skills needed to face the industrial revolution is understanding mathematical concepts (Baiduri, 2019; Collins \& Halverson, 2010; Subekt, Taufiq, Susilo, Ibrohim, \& Suwono, 2018). It is based that understanding mathematical concepts enables one to solve problems better (Griffin, 2004; Kusmanto, 2014; Purwanti, Pratiwi, \& Rinaldi, 2016; Sztajn, Confrey, Wilson, \& Edgington, 2012), have rules in conceptualizing (Holidun, Masykur, Suherman, \& Putra, 2018; Suandito, 2017; Sudarsana, 2016; Yumiati \& Kusumah, 2019), can develop ideas (Achdiyat \& Lestari, 2016; Edwards, 2011; Hutagalung, 2017), so understanding well-developed mathematical concepts (Kleden, Sugi, \& Gerardus, 2018).

The facts in the field show that the average mathematical ability in Lampung province is below the national average, which is 46.48 . The following data is the result of mathematical ability. 


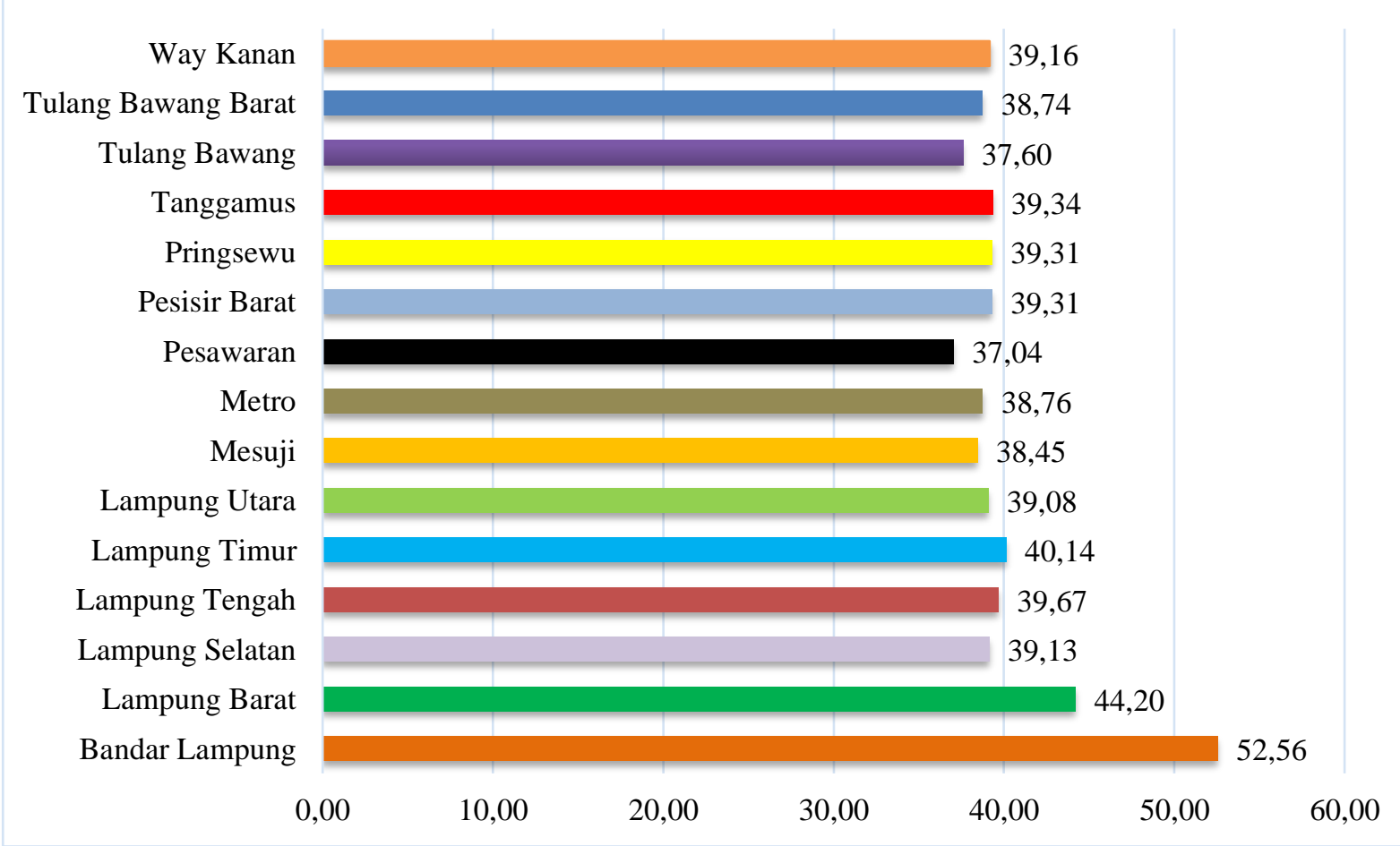

Figure 1. Average Mathematics Ability

The success of understanding mathematical concepts is also influenced by several factors (Andinny, 2015; Mji \& Makgato, 2006; Vandini, 2016), including the learning strategies used (Bruce \& Ross, 2009; Muhamad, 2017). Mathematical learning strategies in the 4.0 era focus on e-learning and blended learning (Karmakar \& Nath, 2014; Mulqueeny, Kostyuk, Baker, \& Ocumpaugh, 2015; Praherdhiono et al., 2019; Setyaningsih, Abdullah, Prihantoro, \& Hustinawaty, 2019). E-learning learning is more flexible (Batalla-Busquets \& Pacheco-Bernal, 2013; Jethro, Grace, \& Thomas, 2012), can foster student knowledge (Fitri, Ifdil, \& Neviyarni, 2016; Goldie, 2016), and foster performance academic.

Based on previous research, e-learning is more effective in promoting better learning performance, can bridge the gap between gender differences in academic performance (Gambari, Shittu, Ogunlade, \& Osunlade, 2018). Also, student motivation and learning outcomes can be increased by the application of blended learning (Sjukur, 2012). So learning by learning will have different learning outcomes and can improve understanding of mathematical concepts (Hanifah, Supriadi, \& Widyastuti, 2019; Ningsih, Misdalina, \& Marhamah, 2017; Saputra, 2017; Wahyuni \& Sugiharta, 2019). Besides, learning 4.0 with Google Classroom is more effective and significantly increased (Savitri, 2019; Solikh, Sulisworo, \& Maruto, n.d.; Zainuddin, 2019)

The difference between this study and previous research lies in cognitive abilities that are measured, namely understanding mathematical concepts with integrating blended learning and 
e-learning. So this aim is to determine the impact of e-learning and blended learning aided by google classroom on the ability of students to understand mathematical concepts.

\section{THE RESEARCH METHODS}

Methods This research method is quasi-experimental. The population in this study were students of class VIII at SMPN 9 Bandar Lampung. The research sample consisted of 90 students consisting of 3 classes. These three classes were given a different treatment, namely the class with blended learning applied, the class that applied E-Learning, and the class with the methods used at each school 30 students. The design of this study is

\section{Tabel 1. Desain Penelitian}

\begin{tabular}{lcc}
\hline \multicolumn{3}{c}{ Learning Model } \\
\hline Blanded learning & E-learning & Conventional \\
\hline
\end{tabular}

The instrument of concept understanding using posttest questions is used as an instrument to find out students' conceptual understanding. The prerequisite data analysis technique uses normality and homogeneity tests. The results of the posttest analysis were analyzed using oneway ANOVA using the SPSS 16.0 application for Windows.

\section{THE RESULTS OF THE RESEARCH AND THE DISCUSSION}

Data were analyzed descriptively to determine the range, highest value, lowest value, average, standard deviation, and variance. The summary of the results of the descriptive analysis is presented in Table 2 .

Table 2. Descriptive Data of Posttest Results

\begin{tabular}{lccccccc}
\hline \multicolumn{1}{c}{ Treatment } & N & Range & Min & Max & Mean & Std. Deviation & Variance \\
\hline Blended Learning & 30 & 29 & 71 & 100 & 82.73 & 7.451 & 55.513 \\
E-Learning & 30 & 36 & 64 & 100 & 80.80 & 8.446 & 71.338 \\
Conventional & 30 & 25 & 61 & 86 & 74.43 & 5.335 & 28.461 \\
\hline
\end{tabular}

Based on Table 2, the average value of Blended Learning learning model treatment is 82.73, the E-Learning model treatment is 80.80 and the conventional method group is 74.43 , the highest average value is in Blended Learning treatment with an average of 82.73. Then the assumption test is carried out, namely the normality test in Table 3 and the homogeneity test, whose results are seen in Table 4B.

Table 3. Normality Testposttest

\begin{tabular}{llllllll}
\hline \multirow{2}{*}{ Group } & \multicolumn{3}{c}{ Kolmogorov-Smirnov } & \multicolumn{3}{c}{ Shapiro-Wilk } \\
\cline { 3 - 8 } & & Statistic & df & p-value & Statistic & Df & p-value \\
\hline \multirow{2}{*}{$\begin{array}{l}\text { posttest } \\
\text { Value }\end{array}$} & Blended Learning & .159 & 30 & .053 & .932 & 30 & .057 \\
\cline { 2 - 8 } & E-Learning & .154 & 30 & .068 & .945 & 30 & .128 \\
\cline { 2 - 8 } & Conventional & .142 & 30 & .124 & .954 & 30 & .213 \\
\hline
\end{tabular}


Table 4. Data Homogeneity Test

\begin{tabular}{llcccc}
\hline & & Levene Statistic & df $_{1}$ & $\mathbf{d f}_{\mathbf{2}}$ & p-value \\
\hline Value & Based on Mean & 2.461 & 2 & 87 & .091 \\
posttest & Based on Median & 2.113 & 2 & 87 & .127 \\
& Based on Median and with adjusted & 2.113 & 2 & 76.823 & .128 \\
& df & & & & \\
& Based on trimmed mean & 2.375 & 2 & 87 & .099 \\
\hline
\end{tabular}

Based on Table 3, it appears that the p-value of the Shapiro-Wilk test in the class that is applied Blended Learning is, the class that is applied E-Learning is and the class with Conventional is, this shows that the p-value of all treatments is greater than the value of $\alpha=$ 0.005. From the data that has been done by the Shapiro-Wilk test, the data is normally distributed. Furthermore, table 4 also shows the p-value> significant level, that is, so it is accepted. Thus, the data is normally distributed and homogeneous.

After knowing that the data is normally distributed and homogeneous, then the one-way ANOVA analysis is tested. An overview of the results of the One-way ANOVA test is presented in Table 5.

Table 5. Hypothesis Test (One-way Anova)

\begin{tabular}{llllll}
\hline & Sum of Squares & df & Mean Square & F & p-value \\
\hline Between Groups & 1131.622 & 2 & 565.811 & 10.929 & .000 \\
\hline Within Groups & 4504.033 & 87 & 51.770 & & \\
\hline Total & 5635.656 & 89 & & & \\
\hline
\end{tabular}

Based on the hypothesis test, the ability to understand mathematical concepts can be seen that the p-value $\leq$ significant level $\alpha=0: 05$, which is then $\mathrm{H}_{0}$ is rejected. It can be concluded that there is an influence on students' understanding of mathematical concepts with the Blended Learning learning model using Google Classroom. After knowing that the data was rejected. So, to find out the equality and differences of the three classes, Scheffe continued testing. The summary of Scheffe's further test results in table 5.

Table 6. Scheffe Further Test Results

\begin{tabular}{lll}
\hline \multicolumn{1}{c}{ Treatment } & p-value & Information \\
\hline Blended Learning dan E-Learning & 0.584 & There is no difference in \\
\hline Blended Learning and Conventional & 0.000 & There are differences in \\
\hline E-Learning dan Conventional & 0.004 & There are differences in \\
\hline
\end{tabular}


The results of this study indicate that the one-way ANOVA calculation on posttest data analysis with $\mathrm{p}$-value $=0.000<\alpha=0.005$ so $\mathrm{H}_{0}$ is rejected, then there is an influence of students 'understanding of mathematical concepts with Blended Learning learning models using Google Classroom and the average ability of students' understanding of mathematical concepts in third learning, namely Blended learning, E-Learning or direct learning there is at least one pair of different classes, between Blended Learning learning models with conventional learning models and E-Learning learning models with conventional learning models.

That is because the factors of students who have an average value of understanding is already high at 74.43 using direct learning, which is commonly applied in schools. From these factors, after the implementation of Blended Learning and E-Learning, learning results in an average value above direct learning, namely 80.80 and 80.73. E-Learning and Blended Learning in internet-based learning use Google Classroom. Google Classroom can help in the repetitive learning process anywhere and anytime. The success factor of learning in understanding concepts is that it can provide facilities for students to easily access the material, collect assignments, and ask teachers outside school hours. Learners can see videos in Google Classroom, although there is no face-to-face learning to use videos in Google Classroom.

There are three possibilities in developing an internet-based learning system, namely a) Web course: this development model fully uses the internet network. In the learning, process E-Learning does not use face-to-face between teachers and students. All learning materials are available via the internet. This learning is called distance learning; b) Web-centric course: this learning model partly uses the internet network and some use face to face. In face-to-face learning, the teacher gives some material and direction to students to learn the subject matter provided on the web on the web and look for relevant material from other sources. Its functions are complementary. In face-to-face learning, more is used for discussions about material students have learned on the web; c) Web-enhanced courses: for this model, the internet is only used for enrichment. The most important learning process is in the classroom. The function of the internet is only to provide knowledge about relevant materials. Therefore teachers are required to master information search techniques, provide direction to students to find sites that are appropriate to the subject matter, serve guidance, and communicate through the internet network (Sofi, 2017).

Blended Learning is a combination of various technological media, activities and types of events to create optimal training programs for specific participants (Sutisna, 2016). The concept of Blended Learning is mixing conventional learning models with online learning. Blended Learning is a valuable concept that can be used to more successfully achieve teaching objectives (Hussin, Siraj, Darusalam, \& Salleh, 2015) It enables students to develop and practice skills outside the classroom whenever and wherever they choose, provided they have access to an internet connection. The addition of E-Learning for classroom teaching provides students with opportunities for independent learning and decentralized knowledge transfer (Choosri Banditvilai, 2016) The application of Blended Learning can provide students selfinterest in learning (Bibi \& Jati, 2015) because students are less satisfied with learning 
conventional class because with Blended Learning they can easily get new material even more up to date from various sources and even experts from all parts of the world (Sjukur, 2012).

The potential for the application of Blended Learning in Indonesia is very high and promising in providing innovation as well as theoretical and practical contributions in solving problems of learning mathematics in Indonesia (Sudiarta \& Sadra, 2016). Utilization of mobile technology with face-to-face learning to increase the competence, creativity and innovation power of students and to make students character (Husamah, 2015). The learning process is done in two directions namely face-to-face (offline) and online using Google Classroom. Educators continue to play a role in providing conducive and active learning conditions / conditions for the material, and assignments students can access in the Google Classroom application. In this learning model, students can access and discuss in the application. Students are said to understand a concept or understand the concept given in the learning process if students can express or explain a concept that is obtained based on their own words, not just memorizing (Ginanjar \& Kusmawati, 2016).

Understanding of mathematical concepts is the basis for learning mathematics meaningfully (Relawati \& Nurasni, 2016). When students still lack in understanding concepts, it will tend to have difficulty in solving problems in the form of reasoning and communicating a concept. Students in attending school are no more than routine to fill in attendance lists, look for grades, and without accompanied by awareness to do all school tasks, add insight or hone skills as a result, many students are less active and their learning results are less satisfying (Widiyasari, 2015).

\section{CONCLUSION AND SUGGESTION}

Based on the results of the study it can be concluded that there are differences in the average value of each treatment of students' understanding of mathematical concepts, where Blended Learning and E-Learning have an impact on understanding mathematical concepts with the help of the same application, Google Classroom, the level of questions the same instrument, as well as an adequate understanding of technology.

Suggestions that can be given to researchers further is that when implementing Blended Learning special training is needed to make a video besides so that students can download the video and can be viewed many times without having to be online. Understanding the mathematical concepts provided through online-based learning is expected to be an educator solution in providing learning by utilizing technology in the industrial era.

\section{REFERENCES}

Achdiyat, M., \& Lestari, K. D. (2016). Prestasi Belajar Matematika Ditinjau dari Kepercayaan Diri dan Keaktifan Siswa di Kelas. Formatif: Jurnal Ilmiah Pendidikan MIPA, 6(1).

Andinny, Y. (2015). Pengaruh konsep diri dan berpikir positif terhadap prestasi belajar matematika siswa. Formatif: Jurnal Ilmiah Pendidikan MIPA, 3(2).

Baiduri, B. (2019). Strategi Literasi dalam Pembelajaran Matematika pada Era Industri 4.0. MUST: Journal of Mathematics Education, Science and Technology, 4(1), 77-94. 
Batalla-Busquets, J.-M., \& Pacheco-Bernal, C. (2013). On-the-job E-learning: Workers' Attitudes and Perceptions. The International Review of Research in Open and Distributed Learning, 14(1), 40-64.

Bibi, S., \& Jati, H. (2015). Efektivitas Model Blended Learning Terhadap Kuliah Algoritma Dan Pemrograman the Effects of Blended Learning Model on the Student' S Motivation and Understanding on the. Jurnal Pendidikan Vokasi, 5(2), 74-87.

Bruce, C. D., \& Ross, J. (2009). Conditions for effective use of interactive on-line learning objects: The case of a fractions computer-based learning sequence. Electronic Journal of Mathematics and Technology, 3(1), 12-29.

Collins, A., \& Halverson, R. (2010). The second educational revolution: Rethinking education in the age of technology. Journal of Computer Assisted Learning, 26(1), 18-27.

Edwards, G. (2011). Concepts of community: A framework for contextualizing distributed leadership. International Journal of Management Reviews, 13(3), 301-312.

Fitri, E., Ifdil, I., \& Neviyarni, S. (2016). Efektivitas layanan informasi dengan menggunakan metode blended learning untuk meningkatkan motivasi belajar. Jurnal Psikologi Pendidikan Dan Konseling: Jurnal Kajian Psikologi Pendidikan Dan Bimbingan Konseling, 2(2), 84-92.

Gambari, A. I., Shittu, A. T., Ogunlade, O. O., \& Osunlade, O. R. (2018). Effectiveness of blended learning and elearning modes of instruction on the performance of undergraduates in Kwara State, Nigeria. MOJES: Malaysian Online Journal of Educational Sciences, 5(1), 25-36.

Ginanjar, G., \& Kusmawati, L. (2016). Peningkatan Kemampuan Pemahaman Konsep Perkalian Melalui Pendekatan Pembelajaran Konstruktivisme Pembelajaran Matematika di Kelas 3 SDN Cibaduyut 4. Jurnal Pendidikan Guru Sekolah Dasar, 1(2), 266. https://doi.org/10.1103/PhysRevA.65.054304

Goldie, J. G. S. (2016). Connectivism: A knowledge learning theory for the digital age? Medical Teacher, 38(10), 1064-1069.

Griffin, S. (2004). Number worlds: A research-based mathematics program for young children. Engaging Young Children in Mathematics: Standards for Early Childhood Mathematics Education, 325-342.

Hanifah, H., Supriadi, N., \& Widyastuti, R. (2019). Pengaruh Model Pembelajaran E-learning Berbantuan Media Pembelajaran Edmodo Terhadap Kemampuan Pemecahan Masalah Matematis Peserta Didik. NUMERICAL: Jurnal Matematika Dan Pendidikan Matematika, 31-42.

Holidun, H., Masykur, R., Suherman, S., \& Putra, F. G. (2018). Kemampuan Pemecahan Masalah Matematis Kelompok Matematika Ilmu Alam dan Ilmu-Ilmu Sosial. Desimal: Jurnal Matematika, 1(1), 29-37.

Husamah. (2015). Pembelajaran Bauran (Blended Learning) (Vol. 9). 
Hussin, Z., Siraj, S., Darusalam, G., \& Salleh, N. H. M. (2015). Kajian Model Blended Learning dalam Jurnal Terpilih: Satu Analisa Kandungan. Jurnal Kurikulum \& Pengajaran Asia Pasifik, 3(1), 1.

Hutagalung, R. (2017). Peningkatan kemampuan pemahaman konsep matematis siswa melalui pembelajaran guided discovery berbasis budaya toba di smp negeri 1tukka. MES (Journal of Mathematics Education and Science), 2(2).

Jethro, O. O., Grace, A. M., \& Thomas, A. K. (2012). E-learning and its effects on teaching and learning in a global age. International Journal of Academic Research in Business and Social Sciences, 2(1), 203.

Karmakar, A., \& Nath, A. (2014). E-Learning Methodologies, Strategies and Tools to implement lifetime education anywhere anytime. International Journal of Innovative Research in Advanced Engineering, 1(4), 193-194.

Kleden, M. A., Sugi, Y., \& Gerardus, U. (2018). Contextual Learning On The Basis of Coastal Culture to Enhance Students' Competency in Mathematical Problems Solving. Journal of Physics: Conference Series, 1108(1), 12013. IOP Publishing.

Kusmanto, H. (2014). Pengaruh Pemahaman Matematika Terhadap Kemampuan Koneksi Matematika Siswa Kelas Vii Semester Genap SMP Negeri 2 Kasokandel Kabupaten Majalengka. Eduma: Mathematics Education Learning and Teaching, 3(2).

Mji, A., \& Makgato, M. (2006). Factors associated with high school learners' poor performance: A spotlight on mathematics and physical science. South African Journal of Education, 26(2), 253-266.

Muhamad, N. (2017). Pengaruh Metode Discovery Learning untuk Meningkatkan Representasi Matematis dan Percaya Diri Siswa. Jurnal Pendidikan UNIGA, 10(1), 9-22.

Mulqueeny, K., Kostyuk, V., Baker, R. S., \& Ocumpaugh, J. (2015). Incorporating effective elearning principles to improve student engagement in middle-school mathematics. International Journal of STEM Education, 2(1), 15.

Ningsih, Y. L., Misdalina, M., \& Marhamah, M. (2017). Peningkatan Hasil Belajar dan Kemandirian Belajar Metode Statistika Melalui Pembelajaran Blended Learning. AlJabar: Jurnal Pendidikan Matematika, 8(2), 155-164.

Praherdhiono, H., Setyosari, P., Degeng, I. N. S., Slamet, T. I., Surahman, E., Adi, E. P., ... Abidin, Z. (2019). Teori dan Implementasi Teknologi Pendidikan: Era Belajar Abad 21 dan Revolusi Industri 4.0. Seribu Bintang.

Purwanti, R. D., Pratiwi, D. D., \& Rinaldi, A. (2016). Pengaruh Pembelajaran Berbatuan Geogebra terhadap Pemahaman Konsep Matematis ditinjau dari Gaya Kognitif. Al-Jabar: Jurnal Pendidikan Matematika, 7(1), 115-122.

Relawati, \& Nurasni. (2016). Memegang Peranan Penting dalam Perkembangan Sains dan Teknologi. Matematika. Mendidik:Jurnal Kajian Pendidikan Dan Pengajaran, 2(1), 162. 
Saputra, J. (2017). Penggunaan model problem based learning berbantuan e-learning terhadap kemandirian belajar mahasiswa pada dimensi tiga. Kalamatika: Jurnal Pendidikan Matematika, 2(2), 117-130.

Savitri, D. I. (2019). Penggunaan Pembelajaran 4.0 Berbantuan Aplikasi Google Classroom Dan Google Form dalam Mata Kuliah Ilmu Sosial Budaya Dasar. Jurnal Borneo Saintek, 2(1), 20-25.

Setyaningsih, R., Abdullah, A., Prihantoro, E., \& Hustinawaty, H. (2019). Model Penguatan Literasi Digital Melalui Pemanfaatan E-Learning. Jurnal ASPIKOM, 3(6), 1200-1214.

Sjukur, S. B. (2012). Pengaruh Blended Learning Terhadap Motivasi Belajar dan Hasil Belajar Siswa Tingkat Smk the Effects of Blended Learning on the Learning Motivation and Achievement Students Level SMK. Jurnal Pendidikan Vokasi, 2(3), 369. https://doi.org/10.21831/JPV.V2I3.1043

Sofi, E. (2017). Pembelajaran Berbasis E-Learning Pada Mata Pelajaran Sejarah Kebudayaan Islam Kelas Viii Madrasah Tsanawiyah Negeri. Tanzhim, 1(01), 49-64.

Solikh, M. N., Sulisworo, D., \& Maruto, G. (n.d.). Pengaruh model pembelajaran blended learning berbantuan google classroom terhadap kemampuan berpikir kritis ditinjau dari self esteem dan kecerdasan intelektual. Jurnal Materi Dan Pembelajaran Fisika, 8(2), $27-32$.

Suandito, B. (2017). Bukti Informal dalam Pembelajaran Matematika. Al-Jabar: Jurnal Pendidikan Matematika, 8(1), 13-24.

Subekt, H., Taufiq, M., Susilo, H., Ibrohim, I., \& Suwono, H. (2018). Mengembangkan Literasi Informasi Melalui Belajar Berbasis Kehidupan Terintegrasi Stem Untuk Menyiapkan Calon Guru Sains Dalam Menghadapi Era Revolusi Industri 4.0: Revieu Literatur. Education and Human Development Journal, 3(1).

Sudarsana, I. K. (2016). Peningkatan Mutu Pendidikan Luar Sekolah Dalam Upayapembangunan Sumber Daya Manusia. Jurnal Penjaminan Mutu, 1(1), 1-14.

Sudiarta, I. G. P., \& Sadra, I. W. (2016). Pengaruh Model Blended Learning Berbantuan Video Animasi terhadap Kemampuan Pemecahan Masalah dan Pemahaman Konsep Siswa. Jurnal Pendidikan Dan Pengajaran, 49(2), 50.

Sutisna, A. (2016). Pengembangan Model Pembelajaran Blended Learning pada Pendidikan Kesetaraan Program Paket C dalam Meningkatkan Kemandirian Belajar. Jurnal Teknologi Pendidikan, 18(3), 158.

Sztajn, P., Confrey, J., Wilson, P. H., \& Edgington, C. (2012). Learning trajectory based instruction: Toward a theory of teaching. Educational Researcher, 41(5), 147-156.

Vandini, I. (2016). Peran kepercayaan diri terhadap prestasi belajar matematika siswa. Formatif: Jurnal Ilmiah Pendidikan MIPA, 5(3). 


\section{$a j \delta \mu$}

Al-Jabar: Jurnal Pendidikan Matematika

Vol. 10, No. 2, 2019, Hal 261 - 270

Wahyuni, D. C., \& Sugiharta, I. (2019). Blended Learning dan E-Learning Berbasis Edmodo Dalam Peningkatan Motivasi Belajar Matematika. Al-Khwarizmi: Jurnal Pendidikan Matematika Dan Ilmu Pengetahuan Alam, 7(1), 1-10.

Widiyasari, R. (2015). Pengembangan Pembelajaran Matematika Konstruktivis Berbantu Elearning untuk Meningkatkan Penguasaan Konsep Matematika Pada Materi SPLDV kelas VIII. FIBONACCI Jurnal Pendidikan Matematika \& Matematika, 1(1), 65.

Yumiati, Y., \& Kusumah, Y. (2019). Interaction between Students' Learning and Early Mathematical Skills to Increase Mathematical Critical Thinking Skills. Al-Jabar: Jurnal Pendidikan Matematika, 10(1), 125-134.

Zainuddin, Z. (2019). Pengembangan Model Pembelajaran Flipped Classroom dengan Taksonomi Bloom pada Mata Kuliah Sistem Politik Indonesia. Jurnal Dimensi Pendidikan Dan Pembelajaran, 7(2), 109-121. 